\title{
MEK and the inhibitors: from bench to bedside
}

\author{
Akintunde Akinleye ${ }^{1}$, Muhammad Furqan ${ }^{1}$, Nikhil Mukhi ${ }^{1}$, Pavan Ravella ${ }^{1}$ and Delong Liu ${ }^{1,2^{*}}$
}

\begin{abstract}
Four distinct MAP kinase signaling pathways involving 7 MEK enzymes have been identified. MEK1 and MEK2 are the prototype members of MEK family proteins. Several MEK inhibitors are in clinical trials. Trametinib is being evaluated by FDA for the treatment of metastatic melanoma with BRAF V600 mutation. Selumetinib has been studied in combination with docetaxel in phase II randomized trial in previously treated patients with advanced lung cancer. Selumetinib group had better response rate and progression-free survival. This review also summarized new MEK inhibitors in clinical development, including pimasertib, refametinib, PD-0325901, TAK733, MEK162 (ARRY 438162), RO5126766, WX-554, RO4987655 (CH4987655), GDC-0973 (XL518), and AZD8330.
\end{abstract}

\section{Introduction}

The mitogen-activated protein kinase (MAPK) signaling pathways involve a family of protein kinases that play critical roles in regulation of diverse cellular activities, including cell proliferation, survival, differentiation, motility, and angiogenesis. The MAPK pathways transduce signals from various extracellular stimuli (growth factors, hormones, cytokines and environmental stresses), leading to distinct intracellular responses via a series of phosphorylation events and protein-protein interactions [1].

Four distinct MAPK cascades have been identified and named according to their MAPK module. These are extracellular signal-regulated kinase (ERK1/2), c-Jun N-terminal kinase (JNK), p38 and ERK5. Each of these cascades comprised of three sequentially acting kinases, activating one after the other (MAPKKK/MAP3K, MAPKK/MAP2K, and MAPK). These signaling cascades are often dysregulated in human cancer cells. Many small molecule inhibitors targeting various component of these cascades are moving quickly from bench to bedside [2-4]. For instance, vemurafenib is the first B-RAF inhibitor that received FDA approval in 2011 for the treatment of BRAF V600E/K mutation positive metastatic melanoma $[5,6]$.

This review focuses on MAP2K or MAPKK component of each of the four MAPK cascades with their characteristics and the small molecule inhibitors targeting these proteins/enzymes. Mitogen-activated protein kinase or

\footnotetext{
* Correspondence: DELONG_LIU@NYMC.EDU

'Department of Medicine, Westchester Medical Center and New York Medical College, Valhalla, NY 10595, USA

2Division of Hematology and Oncology, New York Medical College and Westchester Medical Center, Valhalla, NY, USA
}

MAP2K or MAPKK are commonly known as MEK proteins.

\section{MEK proteins}

MEK proteins belong to a family of enzymes that lie upstream to their specific MAPK targets in each of the four MAP kinase signaling pathways and so far 7 MEK enzymes have been identified (Figure 1). These MEK enzymes selectively phosphorylate serine/threonine and tyrosine residues within the activation loop of their specific MAP kinase substrates [1].

The molecular weight of MEK proteins ranges between 43 and $50 \mathrm{kDa}$. Like all protein kinases, they display a similar structural organization consisting of an aminoterminal domain, a catalytic domain which is also called the kinase domain, and the carboxyl-terminal domain (Figure 2). MEKs share extensive homology in their kinase domain while the amino- and carboxy-termini are more diverse.

MEK1 and MEK2 are closely related (Figure 2). They participate in the Ras/Raf/MEK/ERK signal transduction cascade. MEK 1, also designated as MAPKK-1, is the prototype member of MEK family proteins. It is encoded by the gene $M A P 2 K 1$ located on chromosome 15q22.31. The gene, $M A P 2 K 2$, encoding MEK 2 protein, resides on chromosome 19p13.3. MEK $1 / 2$ proteins consist of a $\mathrm{N}$-terminal sequence, a protein kinase domain, and a $\mathrm{C}$-terminal sequence [7]. The $\mathrm{N}$-terminal sequence contains an inhibitory/allosteric segment, a nuclear export sequence (a unique feature not shared with other MAPKK family members), and a docking site (D-domain) that aids in binding ERK substrates. The kinase domain contains 


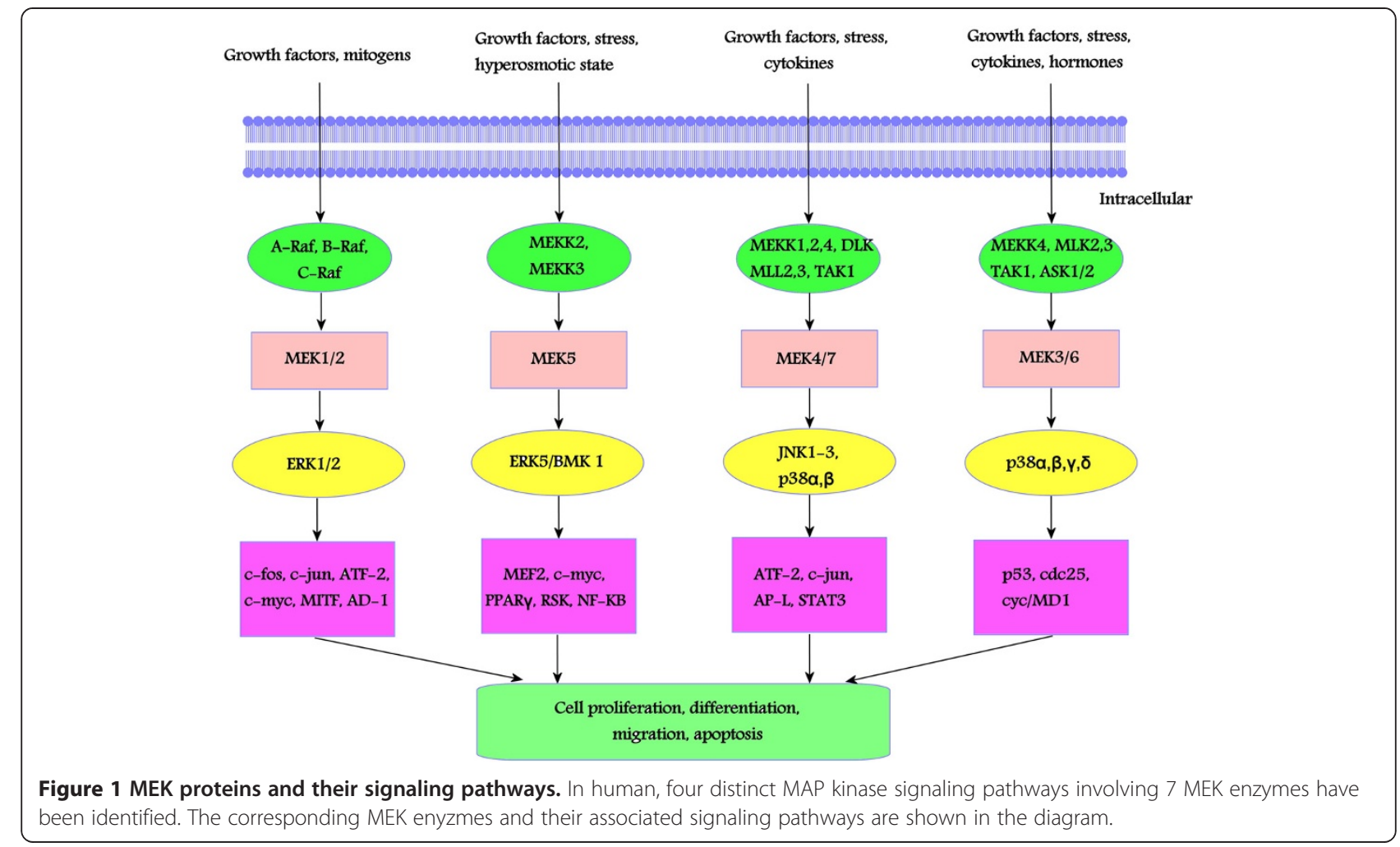

the ATP binding site and catalytic apparatus. The Cterminus houses the domain for versatile docking (DVD) which serves as a major determinant binding site for upstream components of the Ras/Raf/MEK/ERK cascade [8]. MEK $1 / 2$ signaling cascade is activated by ligand binding to receptor tyrosine kinases (RTK), leading to dimerization of the receptors and autophosphorylation of specific tyrosine residues in its $\mathrm{C}$-terminal region. These activated receptors recruit and phosphorylate adaptor proteins Grb2 and SOS, which then interact with membrane-bound GTPase Ras and cause its activation $[9,10]$. H-Ras, K-Ras, and N-Ras function as molecular switches when an inactive Ras-GDP is converted into an active Ras-GTP [11]. In its GTP-bound form, Ras recruits and activates Raf kinases (A-Raf, B-Raf, and C-Raf/RaF-1) [12]. The activated Raf kinases interact and activate MEK $1 / 2$, which in turn catalyze the phosphorylation of threonine and tyrosine residues in the activation sequence Thr-Glu-Tyr of ERK1/2 [10]. Unlike Raf and MEK 1/2 kinases which have narrow substrate specificity, ERK1 and ERK2 have a wide variety of cytosolic and nuclear substrates. Activated ERKs can translocate into the nucleus to initiate diverse cellular responses, such as cell proliferation, survival, differentiation, motility, and angiogenesis. For instance, ERK1/2 signaling promotes the progression of cells from the G0/G1 to $\mathrm{S}$ phase by activation of positive cell cycle regulators cyclin D1 and c-Myc [13,14], and down-regulation of anti-proliferative proteins such as
Tob1, FOXO3a and p21 [15,16]. Similarly the Raf/MEK/ ERK MAP kinase pathway promotes cell survival by blocking NF-kB, leading to increased transcription of antiapoptotic and pro-survival genes like $\mathrm{Bcl}-2$ and $\mathrm{Mcl}-1$ [17]. The Ras/Raf/MEK/ERK signaling is activated in human cancers via several different mechanisms. Increased ERK $1 / 2$ signaling is often due to direct mutational activation or amplification of genes encoding key components of the Ras/Raf/MEK/ERK pathway such as Ras and B-Raf. A large-scale cancer genome sequencing study revealed that B-Raf is mutated in about $20 \%$ of all cancers and in more than $60 \%$ of melanomas [18]. Less commonly ERK $1 / 2$ cascade can also be activated by MEKs in solid tumors including melanoma, colon, and lung carcinomas $[19,20]$.

MEK3 and MEK6 are functionally similar and encoded by $M A P 2 K 3$ and $M A P 2 K 6$ genes, respectively. The genes are both located on chromosome 17q. MEK3 and MEK6 consist of 347 and 334 amino acids residues respectively [21]. Structurally MEK6 differs from MEK3 in terms of $\mathrm{C}$ - and $\mathrm{N}$ - terminal regions. However, the ATP binding sites, and serine/threonine and tyrosine catalytic sites are conserved [22,23]. MEK3/6 signaling pathway is activated by growth factor stimulation through RTKs. Additionally, the cascade can also be activated by Gprotein coupled receptors, intracellular receptors, and toll-like receptors [24], in response to numerous stimuli including physical and chemical stresses, hormones, UV irradiation, and cytokines, such as interleukin-1 and 


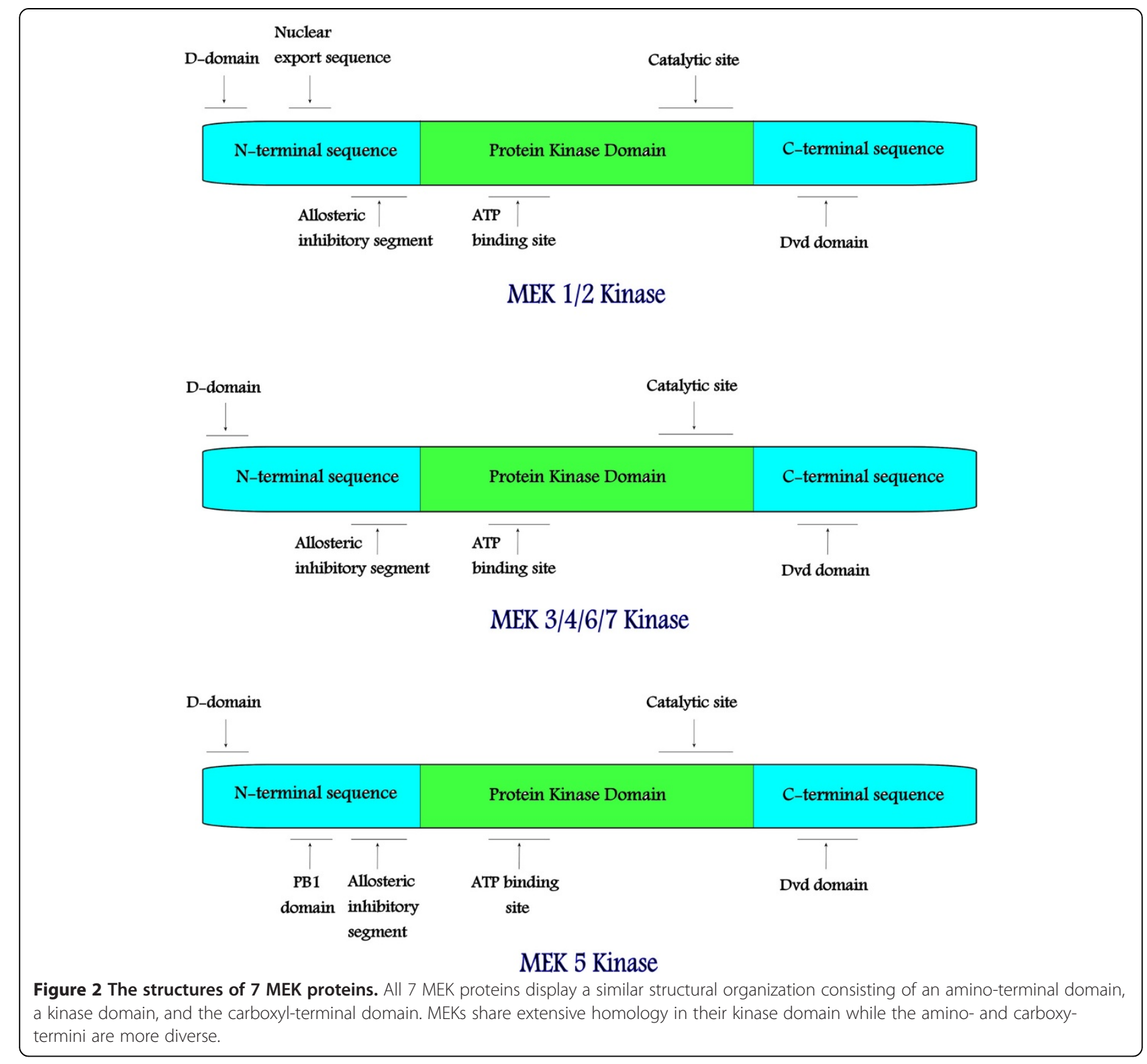

tumor necrosis factor. These stimuli activate different MAPK kinase kinases (MAPKKKs), which include TAK1, ASK1/2, DLK, MEKK4, TAO1/2/3 and MLK2/3 [25]. Active MAPKKKs phosphorylate and activate MEK3/6, which in turn catalyzes the concomitant phosphorylation of a threonine/serine and a tyrosine residue in the p38 MAPK. MEK6 activates all the four isoforms of p38 MAP kinase $(\alpha, \beta, \gamma$ and $\delta$ ) whereas MEK3 can only activate p38 $\alpha$ and p38 $\beta$ isoforms [25]. p38 MAP kinase inhibits G1/S and G2/M cell cycle progression through downregulation of cyclin D1 and Cdc25 expression respectively, both at the level of gene transcription and post-translation [26-28]. In addition, MEK3/6-p38 MAPK cascade promotes p53-dependent growth arrest by phosphorylating p53 at serine 33 and 46 [25]. Together, these targets of
MEK3/6-p38 MAPK pathway (cyclin D1, Cdc25, and p53) cooperate to arrest the cell cycle. Thus decreased p38 activity may play an important role in carcinogenesis. For example, p38 activity has been shown to be reduced in hepatocellular carcinoma in comparison to adjacent normal tissue, with tumor size inversely related to p38 activity [29].

MEK4 and MEK7 are members of the stress-activated protein kinase (SAPK) signaling cascade. MEK4, a product of MAP2K4 gene (chromosome 17p11.2) is composed of 399 amino acids residues, whereas MEK7 is encoded by $M A P 2 K 7$ gene that maps to chromosome 19p13.3 [21]. MEK4 and MEK7 are homologous in their kinase domains which contain 11 subdomains, but their $\mathrm{N}$ - and C- terminal subunits are different [30]. Upon activation by upstream kinases, MAP3Ks including MEKKs (MEKK1-4), 
MLK2/3, Tpl-2, DLK, TAO1/2, TAK1 and ASK1/2 catalyze the phosphorylation of threonine residues in the activation segment of either MEK4 and MEK7 or MEK4 only [8,31]. Activated MEK4/7 work synergistically and activate JNK protein kinases, including JNK1, JNK2, and JNK3. To execute their functions, JNKs activate several transcription factors, including c-Jun, ATF-2, NF-ATc1, HSF-1 and STAT3 [32,33]. MEK4/7-JNK signaling pathway acts as a key tumor suppressive pathway $[34,35]$. It has also been reported that MEK4/7 along with its substrate JNK may promote apoptosis by phosphorylating and inactivating anti-apoptotic proteins $\mathrm{Bcl} 2, \mathrm{Bcl}-\mathrm{XL}$ and $\mathrm{Mcl}-1$ [36]. The MEK-JNK signaling also play an important role during embryogenesis [37]. Transgenic mice studies have shown that MEK4 activity is required for normal hepatogenesis, $\mathrm{B}$ and T-cell lymphopoiesis, and erythropoiesis [38,39]. There is considerable evidence that MEK4-JNK signaling cascade is also a critical mediator of cardiac hypertrophy in response to preload and afterload changes [40]. MEK4, in addition to its principal target, JNK, also crosstalks with MEK3/6-p38MAPK pathway by activating p38 $\alpha$ and p38 $\beta$ [41-43]. MEK4 has been consistently observed to be inactivated by non-sense, missense or deletion mutations in many solid tumors [44]. The expression of MEK4 was shown to be down-regulated in $75 \%$ of cases of serous ovarian cancer [45]. It has been hypothesized that loss of MEK4-p38MAPK signaling cascade may be a relevant pathway associated with tumorigenesis [46].

MEK5 has 448 amino acid residues, and shares $40 \%$ identity with other protein kinases $[47,48]$. The upstream kinases are MEKK2 and MEKK3. Growth factors, oxidative stress and hyperosmotic conditions lead to activation of MEK5 via dual phosphorylation of its serine 311 and threonine 315 residues [49-52]. The best characterized downstream target of MEK5 is ERK5, also known as big MAP kinase 1 (BMK1) because it is twice the size of other MAPKs. The interaction of MEK5 with MEKK2, MEKK3 or ERK5 is mediated by the PB1 domain of MEK5 [53]. Upon activation, ERK5 translocates to the nucleus to stimulate the activity of a number of transcription factors [54-57]. MEK5-ERK5 signaling enhances progression through the cell cycle [58,59]. ERK5 also plays a role in cardiovascular development and neural differentiation [60,61]. Overexpression of MEK5 has been reported in cancers of the colon [62], prostate [63], breast [64], lymphoma [65], and in malignant mesothelioma [66].

\section{MEK inhibitors in clinical trials}

A number of MEK inhibitors have progressed into clinical trials since the first MEK inhibitor (PD098059) was described in the literature in 1995 (Table 1). Currently thirteen MEK inhibitors have been tested clinically but only trametinib (GSK1120212), a selective inhibitor of
MEK 1 and 2, has emerged as the first MEK inhibitor to show favorable clinical efficacy in a phase III trial [67].

MEK inhibitors are sub-divided into two major classes, ATP non-competitive and ATP competitive inhibitors (Figure 3). Most of the known MEK inhibitors are noncompetitive i.e. they do not directly compete for the ATP-binding site. Rather they bind to a unique allosteric site adjacent to the ATP site. This explains the high specificity of the non-competitive MEK inhibitors [68].

\section{Trametinib (GSK1120212, JTP 74057)}

Trametinib (GSK1120212, JTP-74057) is a potent small molecule inhibitor of MEK kinase. It is an allosteric, second generation, ATP non-competitive inhibitor with nanomolar activity against purified MEK 1 and MEK 2 kinases [69]. Preclinical studies showed efficient inhibition of p-ERK $1 / 2$ which correlates with potent cell growth inhibition in tumor lines with mutant B-RAF or Ras. By this mechanism, trametinib induces cell-cycle arrest. In xenograft models of HT-29 and COLO205 colorectal tumor cell lines, trametinib demonstrated robust anticancer activity when administered daily for 14 days $[69,70]$.

An early phase I dose-escalation trial of trametinib ( $\leq 3 \mathrm{mg} /$ day continuous or intermittent dosing schedule) enrolled 206 patients with advanced solid tumors. Dose limiting toxicities included rash, serous central retinopathy and diarrhea. Dose of $2 \mathrm{mg}$ /day was chosen for further studies. Overall objective response rate was $10 \%$. However, B-Raf mutant melanoma had a response rate of 33\% [71]. These encouraging results led to several phase II/III clinical trials of trametinib alone or in combination with other agents [NCT01553851, NCT01682083, NCT01362296, NCT01619774, NCT01245062, details are available on clinicaltrials.gov].

In the first published phase III trial of trametinib, 322 previously treated (interferon or chemotherapy) patients with advanced melanoma with V600E or V600K B-Raf mutations were randomly assigned in a 2:1 ratio to receive oral trametinib ( $2 \mathrm{mg}$ once daily) or intravenous chemotherapy consisting of either dacarbazine $\left(1000 \mathrm{mg} / \mathrm{m}^{2}\right)$ or paclitaxel $\left(175 \mathrm{mg} / \mathrm{m}^{2}\right)$, every 3 weeks [67]. The median progression-free survival (PFS) of patients who received trametinib (4.8 months) was significantly longer than that of patients who received chemotherapy ( 1.5 months) (hazard ratio [HR] 0.45; $\mathrm{P}<0.001$ ). At 6 months, the rate of overall survival was $81 \%$ in the trametinib group versus $67 \%$ in the chemotherapy group (HR 0.54; $\mathrm{P}=0.01$ ).

\section{Pimasertib (AS703026, MSC1936369B)}

Pimasertib, also known as AS703026, MSC1936369B, is a highly potent ATP noncompetitive second generation inhibitor of MEK1 and MEK2 [72,73]. Pimasertib selectively binds to the distinctive allosteric site on MEK1/2 
Table 1 MEK inhibitors in clinical trials

\begin{tabular}{|c|c|c|c|c|c|}
\hline MEK Inhibitors & Target & Clinical trial & Common toxicities & Tumors & References \\
\hline $\begin{array}{l}\text { Trametinib } \\
\text { (GSK1120212) }\end{array}$ & MEK1/2 & III & Rash, diarrhea, retinopathy & Melanoma, colorectal cancer & {$[67]$} \\
\hline $\begin{array}{l}\text { Pimasertib } \\
\text { (AST03026) }\end{array}$ & MEK1/2 & I & $\begin{array}{c}\text { Nausea, rash, visual disturbance, } \\
\text { asthenia }\end{array}$ & Colorectal, multiple myeloma & [74] \\
\hline $\begin{array}{l}\text { Selumetinib } \\
\text { (AZD6244) }\end{array}$ & MEK1 & $\|$ & Nausea, rash, xerostomia & Melanoma, NSCLC & {$[76-85]$} \\
\hline PD-0325901 & MEK1/2 & । & $\begin{array}{l}\text { Rash, fatigue, blurry vision, } \\
\text { diarrhea }\end{array}$ & Melanoma, NSCLC & [89-91] \\
\hline $\begin{array}{l}\text { Refametinib } \\
\text { (RDEA119) }\end{array}$ & MEK1/2 & $\|$ & Rash & $\begin{array}{l}\text { Hepatocellular cancer, melanoma, } \\
\text { colorectal cancer }\end{array}$ & {$[94,95]$} \\
\hline TAK733 & MEK1/2 & । & Not available & Melanoma, NSCLC, colorectal, breast cancer & {$[96,97]$} \\
\hline MEK162 & MEK1/2 & $|/ /| \mid$ & Rash, dermatitis, CPK elevation & N-Ras melanoma, NSCLC, pancreatic cancer & {$[100]$} \\
\hline RO5126766 & Raf/MEK1/2 & I & Rash, diarrhea, CPK elevation & Melanoma & [101] \\
\hline WX-554 & MEK1/2 & $\|$ & Not available & Advanced solid tumors & [102] \\
\hline RO4987655 & MEK1 & I & Rash, Gl disorders & Melanoma & {$[104]$} \\
\hline GDC-0973 & MEK1 & I & $\begin{array}{l}\text { Rash, nausea, dysguesia, } \\
\text { elevated CK }\end{array}$ & $\begin{array}{c}\text { Melanoma, Pancreatic cancer, } \\
\text { endometrial cancer }\end{array}$ & {$[108]$} \\
\hline AZD8330 & MEK1/2 & I & $\begin{array}{l}\text { Mental status change, } \\
\text { rash, nausea }\end{array}$ & Advanced solid tumors & {$[110]$} \\
\hline
\end{tabular}
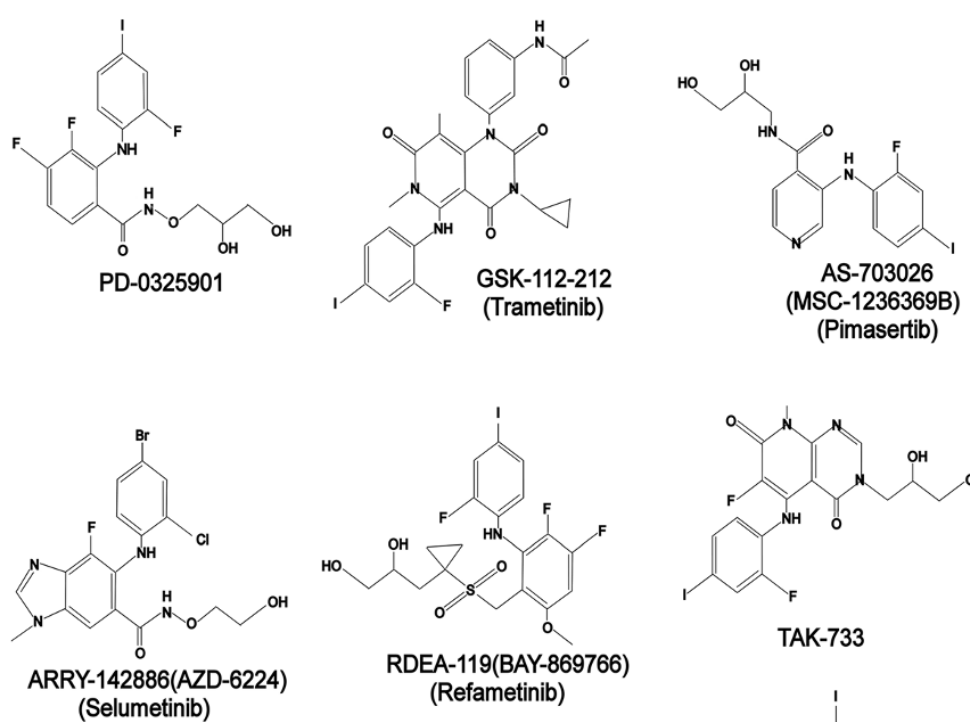

(Refametinib)
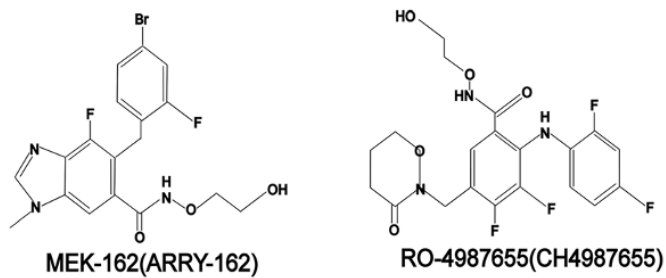
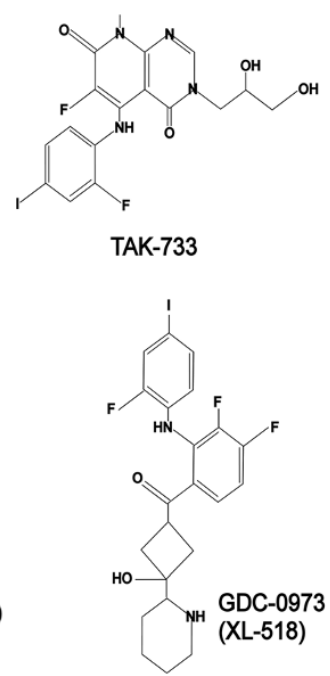

Figure 3 The chemical structures of $\mathbf{9}$ MEK inhibitors in clinical development. Nine MEK inhibitors are shown in the diagram. Among them, trametinib is being evaluated by FDA for treatment of advanced metastatic melanoma. 
[73]. In xenograft models, pimasertib demonstrated significant tumor growth inhibition in a human plasmacytoma H929 MM cell line at 15 and $30 \mathrm{mg} / \mathrm{kg}$ for 21 days [72]. Tumor regression was also observed at $10 \mathrm{mg} / \mathrm{kg}$ in a mouse model of D-MUT colorectal tumor [73].

A multicenter phase I/II clinical trial of pimasertib plus FOLFIRI as a second line treatment in K-Ras mutated metastatic colorectal cancer (mCRC) enrolled 16 patients [74]. Initially no DLT was observed at $45 \mathrm{mg} /$ day which allowed dose escalation to $60 \mathrm{mg} /$ day. At this dose, 2 of 5 patients experienced grade 3 mucositis/stomatitis leading the expansion of $45 \mathrm{mg} /$ day cohort. Most common treatment-emergent adverse events (TEAEs) after 3 cycles of treatment were asthenia, diarrhea, mucositis, ocular events, nausea, rash and vomiting. These TEAEs were observed in more than one third of the treated subjects. Currently, a few phase I/II studies are underway to test pimasertib (MSC1936369B) in the setting of advanced or metastatic solid tumors including melanoma [NCT01016483, NCT01016483, NCT016968017, NCT01453387].

\section{Selumetinib (AZD6244, ARRY-142886)}

Selumetinib is a non-ATP competitive highly selective MEK 1/2 inhibitor with IC50 of $14 \mathrm{~nm}$ [75]. In xenograft models, its antitumor activity correlates with decrease in phosphorylated ERK1/2 levels.

In a phase I dose escalation study of 57 patients with advanced cancers, a total daily dose of $200 \mathrm{mg}$ was suggested for subsequent trials [76]. Rash, diarrhea and hypoxia were reported as major DLTs. At the recommended dose of $100 \mathrm{mg}$ bid most of these TEAEs were grade 1 or 2 . Other common TEAEs were nausea, fatigue, peripheral edema, transaminitis and blurry vision. Best response was stable disease and achieved in 33\% of patient at the end of $2^{\text {nd }}$ cycle. Patients with mutated Ras or Raf remained longer in the study with higher response rate but analysis of statistical significance could not be performed due to small number of patients.

Multiple phase II studies were conducted in patients with papillary thyroid, lung, liver, pancreatic, colorectal cancers and melanoma [77-82]. Patients in these trials received selumetinib irrespective of Ras/Raf mutation status and none of these trials met their primary end points. However, patients harboring Ras/Raf mutations had higher objective response rate, indicating the need of proper patient selection in subsequent studies evaluating selumetinib.

A randomized placebo controlled phase II trial was done in previously treated patients with K-Ras mutant stage III-IV non-small cell lung cancer (NSCLC) [83]. Patients were randomized to receive docetaxel plus either placebo or selumetinib (75 mg twice daily q21 days), with overall survival (OS) being the primary end point.
Median OS was 9.4 months $(\mathrm{m})$ in selumetinib arm vs $5.2 \mathrm{~m}$ in control arm, yet the difference was statistically non-significant (HR 0.8, 80\% CI 0.56-1.14, p=0.21). However, median progression free survival was significantly prolonged in selumetinib arm $(5.3 \mathrm{~m})$ compared to control arm $(2.1 \mathrm{~m})$. Overall response rate was also better in selumetinib group. The combination of docetaxel and selumetinib had higher toxicity than docetaxel alone. Selumitinib was also studied in recurrent low grade serous carcinoma of the ovary/peritoneum in a single arm phase II study and in mitigating radioactive iodine refractoriness in metastatic thyroid cancer $[84,85]$.

\section{PD-0325901}

PD-0325901 is a highly specific and potent synthetic analog of MEK inhibitor CI-1040. It has subnanomolar and non-competitive inhibitory activity (IC50 = $0.33 \mathrm{nM})$ against purified MEK 1 and MEK 2 [86]. PD-0325901 inhibited phosphorylation of ERK1/2 in melanoma and papillary thyroid cancer (PTC) cell lines harboring BRaf mutation [87]. In xenograft models, PD-0325901 demonstrated significant antitumor activity at a dose of $20-25 \mathrm{mg} / \mathrm{kg} /$ day with tumor shrinkage by $58 \%$ in PTC cells with the RET/PTC1 rearrangement [88].

In a phase I, dose-escalation study of 30 patients with multiple solid tumors, the DLTs were acneiform rash involving face, trunk and arms at $30 \mathrm{mg}$ twice daily. Transient and reversible visual effects characterized by blurred vision and halos were observed at $\geq 15 \mathrm{mg}$ BID $[89,90]$. The most frequent treatment-emergent adverse events (TEAE) included rash, fatigue, diarrhea, nausea, and vomiting. There were $1 \mathrm{PR}$ (melanoma) and $5 \mathrm{SD}$ (4 melanomas, 1 NSCLC). In an open-label, phase II study, patients with progressive, recurrent, or advanced NSCLC were treated with15 mg PD-0325901 twice daily [91]. There were no objective responses during the trial period. Due to a lack of responses coupled with the safety issues, the trial was closed after the first stage. However, Pfizer initiated a new multi-arm phase 1 study in 2012 to test PF-04691502 and PF-05212384, dual $\mathrm{PI} 3 \mathrm{~K} / \mathrm{mTOR}$ Inhibitors in combination with PD0325901 or irinotecan in patients with advanced cancer [NCT01347866].

\section{Refametinib (RDEA119, BAY 869766)}

Refametinib is the only cyclopropane-1-sulfonamide derivative, and exhibits a highly selective allosteric inhibition of MEK 1/2 [92]. When dosed once daily for 14 days, refametinib showed potent activity in preclinical xenografts of human melanoma A375, colon carcinoma Colo205 and HT-29, pancreatic cancer OCIP19, 21, and 23, and skin carcinoma A431 tumor models [92,93].

In a phase I/II study of patients with advanced solid tumors, refametinib was well tolerated at doses $100 \mathrm{mg}$ 
daily. Rash was the most common TEAE [94]. Subsequently, a phase II study enrolled seventy patients to evaluate refametinib in combination with sorafenib as first-line treatment for unresectable hepatocellular carcinoma (HCC) [95]. Of sixty-five patients analyzed for efficacy per protocol, three (5\%) had PR, and the median time-to-progression was 4.1 months.

\section{TAK733}

TAK733 is a novel second-generation, allosteric kinase inhibitor with potent anti-MEK 1/2 activity [96]. In xenograft models, TAK-733 exhibited broad antitumor properties $[96,97]$. Phase I/II trials using TAK733 alone and in combination with alisertib in advanced non-hematologic malignancies are still accruing [NCT00948467, NCT01613261].

\section{MEK162 (ARRY 438162)}

MEK162 (ARRY 438162) is another novel, second generation inhibitor that targets MEK $1 / 2[98,99]$. A phase II study examined MEK162 in 71 patients with N-Ras and B-Raf mutated advanced melanoma patients. It was given as $45 \mathrm{mg}$ twice daily. Disease control rates of $63 \%$ and $51 \%$ were noticed in N-Ras and B-Raf mutant melanoma patients, respectively. No complete response was observed. Grade 3-4 adverse events include rash, diarrhea, fluid retention and creatinine phosphokinase (CPK) elevation [100]. A MEK162 analog, ARRY 300, recently completed phase I testing in healthy volunteers in the United States (NCT00828165).

\section{R05126766}

As a novel, highly potent, first-in-class dual MEK/Raf inhibitor, RO5126766 selectively binds to MEK $1 / 2$ to form a stable Raf-MEK-RO5126766 complex. Cell cycle arrest was shown to be the primary mechanism for the growth-inhibitory properties of RO5126766 in a panel of human tumor cell lines [101].

A phase I open-label, dose-escalation study of RO5126766 was undertaken in 52 patients with advanced cancers [101]. Tolerability of RO5126766 was similar to that of other MEK inhibitors and the most common toxicities included rash-related disorders, elevated CPK, and diarrhea. The overall objective response rate was $40 \%$ in forty-five patients. Of 21 patients with metastatic melanoma included in the study, three PR were seen in two B-Raf mutant melanomas and one in an N-Ras mutant melanoma. The dose recommended for phase II investigation was $2.7 \mathrm{mg}$ daily 4 days on/ 3 days off.

\section{WX-554}

WX-554 is another MEK 1/2 inhibitor. To determine pharmacokinetic and pharmacodynamic parameters, WX-554 is planned to be administered intravenously as single doses in the range of $0.05 \mathrm{mg} / \mathrm{kg}$ to $5.0 \mathrm{mg} / \mathrm{kg}$ to healthy volunteers in dose escalated manner [102]. Results of this study are not available yet. An oral formulation of this inhibitor is being tested in a phase I/II trial in patients with advanced solid tumors (NCT01581060).

\section{R04987655 (CH4987655)}

RO4987655 is a highly selective, small molecule MEK inhibitor. The unique 3-oxo-oxazinane ring structure of RO4987655 confers metabolic stability, This compound showed slow dissociation from MEK with remarkable antitumor efficacy, and insignificant MEK inhibition in mouse brain, implying few CNS-related side effects in human [103].

In a recently published phase I study of RO4987655, MEK 1 inhibition in cancers was demonstrated by decreased ERK1/2 phosphorylation. Partial responses and stable disease were achieved below MTD (8.5 mg twice daily) mainly in patients with skin melanomas [104]. DLTs were reversible grade 3 blurry vision and grade 3-4 elevation of CPK. The compound alone is currently undergoing further clinical development in an expansion of this study [NCT00817518].

\section{GDC-0973 (XL518)}

A derivative of methanone, GDC-0973 is a potent, orally bioavailable, small-molecule inhibitor of MEK 1 [105]. GDC-0973 showed strong antineoplastic activity in a BRaf and K-Ras mutant cancer cell lines [105-107].

In a phase I clinical trial of 46 evaluable patients, GDC0973 in combination with GDC-0941 induced PR in 3 patients (B-Raf melanoma, B-Raf pancreatic cancer, K-Ras endometrioid cancer) and stable disease in 5 [108]. Safety data showed that the DLTs were increase in serum lipase and CK enzymes. Additional phase I-III clinical trials are ongoing [NCT01689519, NCT01271803, NCT00996892, NCT01271803, NCT01562275].

\section{AZD8330 (ARRY-424704, ARRY-704)}

AZD8330 (ARRY 704) represents a new member of MEK1/2 inhibitors [109]. A large phase I trial of 82 patients with advanced solid tumors defined the MTD to be $40 \mathrm{mg} /$ day. Change in mental status was the dose limiting toxicity. Other common TEAEs include rash, fatigue, diarrhea and vomiting. Disease control rate of $40 \%$ was demonstrated in this study. Mutation analysis of Ras/Raf genes were not mandated by the study [110].

\section{Conclusions and future directions}

Four distinct MAP kinase signaling pathways involving 7 MEK enzymes have been identified. MEK1 and MEK2 are the prototype members of MEK family proteins. Several MEK inhibitors are in clinical trials. Trametinib is being evaluated by FDA for the treatment of 
metastatic melanoma. Targeted therapies with small molecular inhibitors for solid tumors and hematological malignancies are moving quickly from bench to bedside [111-113]. Combination of targeting agents against different signaling pathways may provide additional benefits and warrant further clinical studies [114,115].

\section{Competing interests}

The authors have no relevant competing interest.

\section{Authors' contributions}

All authors have contributed to data preparation, drafting and revising the manuscripts. All authors have read and approved the final manuscript.

\section{Acknowledgment}

This study was partly supported by New York Medical College Blood Diseases Fund.

Received: 13 March 2013 Accepted: 5 April 2013

Published: 12 April 2013

\section{References}

1. Chang L, Karin M: Mammalian MAP kinase signalling cascades. Nature 2001, 410(6824):37-40

2. Thompson N, Lyons J: Recent progress in targeting the Raf/MEK/ERK pathway with inhibitors in cancer drug discovery. Curr Opin Pharmacol 2005, 5(4):350-356.

3. Hsueh C-T, Liu D, Wang H: Novel biomarkers for diagnosis, prognosis, targeted therapy and clinical trials. Biomarker Res 2013, 1(1):1.

4. Furqan M, Mukhi N, Lee B, Liu D: Dysregulation of JAK-STAT pathway in hematological malignancies and JAK inhibitors for clinical application. Biomarker Res 2013, 1(1):5.

5. Chapman PB, Hauschild A, Robert C, Haanen JB, Ascierto P, Larkin J, Dummer R, Garbe C, Testori A, Maio M, et al: Improved survival with vemurafenib in melanoma with BRAF V600E mutation. $N$ Engl J Med 2011, 364(26):2507-2516

6. Lee B, Mukhi N, Liu D: Current management and novel agents for malignant melanoma. J Hematol Oncol 2012, 5:3.

7. Fischmann TO, Smith CK, Mayhood TW, Myers JE, Reichert P, Mannarino A, Carr D, Zhu H, Wong J, Yang RS, et al: Crystal structures of MEK1 binary and ternary complexes with nucleotides and inhibitors. Biochemistry 2009, 48(12):2661-2674.

8. Takekawa M, Tatebayashi K, Saito H: Conserved docking site is essential for activation of mammalian MAP kinase kinases by specific MAP kinase kinase kinases. Mol Cell 2005, 18(3):295-306.

9. Liang H, Liu T, Chen F, Liu Z, Liu S: A full-length 3D structure for MAPK/ ERK kinase 2 (MEK2). Sci China Life Sci 2011, 54(4):336-341.

10. Sacks DB: The role of scaffold proteins in MEK/ERK signalling. Biochem Soc Trans 2006, 34(Pt 5):833-836.

11. Pylayeva-Gupta Y, Grabocka E, Bar-Sagi D: RAS oncogenes: weaving a tumorigenic web. Nat Rev Cancer 2011, 11(11):761-774.

12. Roskoski R Jr: RAF protein-serine/threonine kinases: structure and regulation. Biochem Biophys Res Commun 2010, 399(3):313-317.

13. Roovers K, Assoian RK: Integrating the MAP kinase signal into the G1 phase cell cycle machinery. Bioessays 2000, 22(9):818-826.

14. Sears R, Nuckolls F, Haura E, Taya Y, Tamai K, Nevins JR: Multiple Rasdependent phosphorylation pathways regulate Myc protein stability. Genes Dev 2000, 14(19):2501-2514

15. Hwang CY, Lee C, Kwon KS: Extracellular signal-regulated kinase 2 dependent phosphorylation induces cytoplasmic localization and degradation of p21Cip1. Mol Cell Biol 2009, 29(12):3379-3389.

16. Yang JY, Zong CS, Xia W, Yamaguchi H, Ding Q, Xie X, Lang JY, Lai CC, Chang $\mathrm{CJ}$, Huang WC, et al: ERK promotes tumorigenesis by inhibiting FOXO3a via MDM2-mediated degradation. Nat Cell Bio/ 2008, 10(2):138-148

17. Balmanno K, Cook SJ: Tumour cell survival signalling by the ERK $1 / 2$ pathway. Cell Death Differ 2009, 16(3):368-377.

18. Davies H, Bignell GR, Cox C, Stephens P, Edkins S, Clegg S, Teague J, Woffendin H, Garnett MJ, Bottomley W, et al: Mutations of the BRAF gene in human cancer. Nature 2002, 417(6892):949-954.
19. Marks JL, Gong Y, Chitale D, Golas B, McLellan MD, Kasai Y, Ding L, Mardis ER, Wilson RK, Solit D, et al: Novel MEK1 mutation identified by mutational analysis of epidermal growth factor receptor signaling pathway genes in lung adenocarcinoma. Cancer Res 2008, 68(14):5524-5528.

20. Murugan AK, Dong J, Xie J, Xing M: MEK1 mutations, but not ERK2 mutations, occur in melanomas and colon carcinomas, but none in thyroid carcinomas. Cell Cycle 2009, 8(13):2122-2124.

21. Rampoldi L, Zimbello R, Bortoluzzi S, Tiso N, Valle G, Lanfranchi G, Danieli GA Chromosomal localization of four MAPK signaling cascade genes: MEK1, MEK3, MEK4 and MEKK5. Cytogenet Cell Genet 1997, 78(3-4):301-303.

22. Han J, Lee JD, Jiang Y, Li Z, Feng L, Ulevitch RJ: Characterization of the structure and function of a novel MAP kinase kinase (MKK6). J Biol Chem 1996, 271(6):2886-2891.

23. Stein B, Brady H, Yang MX, Young DB, Barbosa MS: Cloning and characterization of MEK6, a novel member of the mitogen-activated protein kinase kinase cascade. J Biol Chem 1996, 271(19):11427-11433.

24. Virtue A, Wang H, Yang X-f: MicroRNAs and Toll-like Receptor/Interleukin1 Receptor Signaling. J Hematol Oncol 2012, 5(1):66.

25. Zarubin T, Han J: Activation and signaling of the p38 MAP kinase pathway. Cell Res 2005, 15(1):11-18.

26. Brancho D, Tanaka N, Jaeschke A, Ventura JJ, Kelkar N, Tanaka Y, Kyuuma M, Takeshita T, Flavell RA, Davis RJ: Mechanism of p38 MAP kinase activation in vivo. Genes Dev 2003, 17(16):1969-1978

27. Bulavin DV, Fornace AJ Jr: p38 MAP kinase's emerging role as a tumor suppressor. Adv Cancer Res 2004, 92:95-118.

28. Bulavin DV, Higashimoto Y, Popoff IJ, Gaarde WA, Basrur V, Potapova O, Appella E, Fornace AJ Jr: Initiation of a G2/M checkpoint after ultraviolet radiation requires p38 kinase. Nature 2001, 411(6833):102-107.

29. Iyoda K, Sasaki Y, Horimoto M, Toyama T, Yakushijin T, Sakakibara M, Takehara T, Fujimoto J, Hori M, Wands JR, et al: Involvement of the p38 mitogen-activated protein kinase cascade in hepatocellular carcinoma. Cancer 2003, 97(12):3017-3026.

30. Hanks SK, Quinn AM, Hunter T: The protein kinase family: conserved features and deduced phylogeny of the catalytic domains. Science 1988, 241(4861):42-52

31. Kyriakis JM, Avruch J: Mammalian mitogen-activated protein kinase signal transduction pathways activated by stress and inflammation. Physiol Rev 2001, 81(2):807-869.

32. Eferl R, Ricci R, Kenner L, Zenz R, David JP, Rath M, Wagner EF: Liver tumor development. c-Jun antagonizes the proapoptotic activity of p53. Cell 2003, 112(2):181-192.

33. Ip YT, Davis RJ: Signal transduction by the c-Jun N-terminal kinase (JNK)from inflammation to development. Curr Opin Cell Biol 1998, 10(2):205-219.

34. Putcha GV, Le S, Frank S, Besirli CG, Clark K, Chu B, Alix S, Youle RJ, LaMarche A, Maroney AC, et al: JNK-mediated BIM phosphorylation potentiates BAX-dependent apoptosis. Neuron 2003, 38(6):899-914

35. Tournier C, Hess P, Yang DD, Xu J, Turner TK, Nimnual A, Bar-Sagi D, Jones $\mathrm{SN}$, Flavell RA, Davis RJ: Requirement of JNK for stress-induced activation of the cytochrome c-mediated death pathway. Science 2000, 288(5467):870-874

36. Deng X, Xiao L, Lang W, Gao F, Ruvolo P, May WS Jr: Novel role for JNK as a stress-activated Bcl2 kinase. J Biol Chem 2001, 276(26):23681-23688.

37. Xu P, Davis RJ: c-Jun NH2-terminal kinase is required for lineage-specific differentiation but not stem cell self-renewal. Mol Cell Biol 2010, 30(6):1329-1340.

38. Ganiatsas S, Kwee L, Fujiwara Y, Perkins A, Ikeda T, Labow MA, Zon LI: SEK1 deficiency reveals mitogen-activated protein kinase cascade crossregulation and leads to abnormal hepatogenesis. Proc Natl Acad Sci USA 1998, 95(12):6881-6886.

39. Nishina H, Bachmann M, Oliveira-dos-Santos AJ, Kozieradzki I, Fischer KD, Odermatt B, Wakeham A, Shahinian A, Takimoto H, Bernstein A, et al: Impaired CD28-mediated interleukin 2 production and proliferation in stress kinase SAPK/ERK1 kinase (SEK1)/mitogen-activated protein kinase kinase 4 (MKK4)-deficient T lymphocytes. J Exp Med 1997, 186(6):941-953.

40. Choukroun G, Hajjar R, Fry S, del Monte F, Haq S, Guerrero JL, Picard M, Rosenzweig A, Force T: Regulation of cardiac hypertrophy in vivo by the stress-activated protein kinases/c-Jun $\mathrm{NH}(2)$-terminal kinases. J Clin Invest 1999, 104(4):391-398.

41. Derijard B, Raingeaud J, Barrett T, Wu IH, Han J, Ulevitch RJ, Davis RJ: Independent human MAP-kinase signal transduction pathways defined by MEK and MKK isoforms. Science 1995, 267(5198):682-685. 
42. Jiang Y, Chen C, Li Z, Guo W, Gegner JA, Lin S, Han J: Characterization of the structure and function of a new mitogen-activated protein kinase (p38beta). J Biol Chem 1996, 271(30):17920-17926.

43. Lin A, Minden A, Martinetto H, Claret FX, Lange-Carter C, Mercurio F, Johnson $G L$, Karin M: Identification of a dual specificity kinase that activates the Jun kinases and p 38-Mpk2. Science 1995, 268(5208):286-290.

44. Cunningham SC, Gallmeier E, Hucl T, Dezentje DA, Calhoun ES, Falco G, Abdelmohsen K, Gorospe M, Kern SE: Targeted deletion of MKK4 in cancer cells: a detrimental phenotype manifests as decreased experimental metastasis and suggests a counterweight to the evolution of tumorsuppressor loss. Cancer Res 2006, 66(11):5560-5564.

45. Nakayama K, Nakayama N, Davidson B, Katabuchi H, Kurman RJ, Velculescu VE, Shih le M, Wang TL: Homozygous deletion of MKK4 in ovarian serous carcinoma. Cancer Biol Ther 2006, 5(6):630-634.

46. Hickson JA, Huo D, Vander Griend DJ, Lin A, Rinker-Schaeffer CW, Yamada SD: The p38 kinases MKK4 and MKK6 suppress metastatic colonization in human ovarian carcinoma. Cancer Res 2006, 66(4):2264-2270.

47. English JM, Vanderbilt CA, Xu S, Marcus S, Cobb MH: Isolation of MEK5 and differential expression of alternatively spliced forms. J Biol Chem 1995, 270(48):28897-28902.

48. Zhou G, Bao ZQ, Dixon JE: Components of a new human protein kinase signal transduction pathway. J Biol Chem 1995, 270(21):12665-12669.

49. Chao TH, Hayashi M, Tapping RI, Kato $Y$, Lee JD: MEKK3 directly regulates MEK5 activity as part of the big mitogen-activated protein kinase 1 (BMK1) signaling pathway. J Biol Chem 1999, 274(51):36035-36038.

50. Kamakura S, Moriguchi T, Nishida E: Activation of the protein kinase ERK5/ BMK1 by receptor tyrosine kinases. Identification and characterization of a signaling pathway to the nucleus. J Biol Chem 1999, 274(37):26563-26571.

51. Kato Y, Kravchenko W, Tapping RI, Han J, Ulevitch RJ, Lee JD: BMK1/ERK5 regulates serum-induced early gene expression through transcription factor MEF2C. EMBO J 1997, 16(23):7054-7066

52. Sun W, Kesavan K, Schaefer BC, Garrington TP, Ware M, Johnson NL, Gelfand EW, Johnson GL: MEKK2 associates with the adapter protein Lad/RIBP and regulates the MEK5-BMK1/ERK5 pathway. J Biol Chem 2001, 276(7):5093-5100.

53. Nakamura K, Uhlik MT, Johnson NL, Hahn KM, Johnson GL: PB1 domaindependent signaling complex is required for extracellular signalregulated kinase 5 activation. Mol Cell Biol 2006, 26(6):2065-2079.

54. Akaike M, Che W, Marmarosh NL, Ohta S, Osawa M, Ding B, Berk BC, Yan C, Abe J: The hinge-helix 1 region of peroxisome proliferator-activated receptor gamma1 (PPARgamma1) mediates interaction with extracellular signal-regulated kinase 5 and PPARgamma1 transcriptional activation: involvement in flow-induced PPARgamma activation in endothelial cells. Mol Cell Biol 2004, 24(19):8691-8704.

55. English JM, Pearson G, Baer R, Cobb MH: Identification of substrates and regulators of the mitogen-activated protein kinase ERK5 using chimeric protein kinases. J Biol Chem 1998, 273(7):3854-3860.

56. Kasler HG, Victoria J, Duramad O, Winoto A: ERK5 is a novel type of mitogen-activated protein kinase containing a transcriptional activation domain. Mol Cell Biol 2000, 20(22):8382-8389.

57. Terasawa K, Okazaki K, Nishida E: Regulation of c-Fos and Fra-1 by the MEK5-ERK5 pathway. Genes Cells 2003, 8(3):263-273.

58. Kato Y, Tapping RI, Huang S, Watson MH, Ulevitch RJ, Lee JD: Bmk1/Erk5 is required for cell proliferation induced by epidermal growth factor. Nature 1998, 395(6703):713-716.

59. Wang $X$, Tournier $C$ : Regulation of cellular functions by the ERK5 signalling pathway. Cell Signal 2006, 18(6):753-760.

60. Nishimoto S, Kusakabe M, Nishida E: Requirement of the MEK5-ERK5 pathway for neural differentiation in Xenopus embryonic development. EMBO Rep 2005, 6(11):1064-1069

61. Regan CP, Li W, Boucher DM, Spatz S, Su MS, Kuida K: Erk5 null mice display multiple extraembryonic vascular and embryonic cardiovascular defects. Proc Natl Acad Sci USA 2002, 99(14):9248-9253.

62. Hu B, Ren D, Su D, Lin H, Xian Z, Wan X, Zhang J, Fu X, Jiang L, Diao D, et al: Expression of the phosphorylated MEK5 protein is associated with TNM staging of colorectal cancer. BMC Cancer 2012, 12:127.

63. Mehta PB, Jenkins BL, McCarthy L, Thilak L, Robson CN, Neal DE, Leung HY: MEK5 overexpression is associated with metastatic prostate cancer, and stimulates proliferation, MMP-9 expression and invasion. Oncogene 2003, 22(9):1381-1389.

64. Esparis-Ogando A, Diaz-Rodriguez E, Montero JC, Yuste L, Crespo P, Pandiella A: Erk5 participates in neuregulin signal transduction and is constitutively active in breast cancer cells overexpressing ErbB2. Mol Cell Biol 2002, 22(1):270-285.

65. Nagel S, Burek C, Venturini L, Scherr M, Quentmeier H, Meyer C, Rosenwald A, Drexler HG, MacLeod RA: Comprehensive analysis of homeobox genes in Hodgkin lymphoma cell lines identifies dysregulated expression of HOXB9 mediated via ERK5 signaling and BMI1. Blood 2007, 109(7):3015-3023.

66. Ramos-Nino ME, Blumen SR, Sabo-Attwood T, Pass H, Carbone M, Testa JR, Altomare DA, Mossman BT: HGF mediates cell proliferation of human mesothelioma cells through a PI3K/MEK5/Fra-1 pathway. Am J Respir Cell Mol Biol 2008, 38(2):209-217.

67. Flaherty KT, Robert C, Hersey P, Nathan P, Garbe C, Milhem M, Demidov LV, Hassel JC, Rutkowski P, Mohr P, et al: Improved survival with MEK inhibition in BRAF-mutated melanoma. N Engl J Med 2012, 367(2):107-114.

68. Wallace EM, Lyssikatos JP, Yeh T, Winkler JD, Koch K: Progress towards therapeutic small molecule MEK inhibitors for use in cancer therapy. Curr Top Med Chem 2005, 5(2):215-229.

69. Yamaguchi T, Kakefuda R, Tajima N, Sowa Y, Sakai T: Antitumor activities of JTP-74057 (GSK1120212), a novel MEK1/2 inhibitor, on colorectal cancer cell lines in vitro and in vivo. Int J Oncol 2011, 39(1):23-31.

70. Gilmartin AG, Bleam MR, Groy A, Moss KG, Minthorn EA, Kulkarni SG, Rominger CM, Erskine S, Fisher KE, Yang J, et al: GSK1120212 (JTP-74057) is an inhibitor of MEK activity and activation with favorable pharmacokinetic properties for sustained in vivo pathway inhibition. Clin Cancer Res 2011, 17(5):989-1000.

71. Infante JR, Fecher LA, Falchook GS, Nallapareddy S, Gordon MS, Becerra C, DeMarini DJ, Cox DS, Xu Y, Morris SR, et al: Safety, pharmacokinetic, pharmacodynamic, and efficacy data for the oral MEK inhibitor trametinib: a phase 1 dose-escalation trial. Lancet Oncol 2012, 13(8):773-781.

72. Kim K, Kong SY, Fulciniti M, Li X, Song W, Nahar S, Burger P, Rumizen MJ, Podar K, Chauhan D, et al: Blockade of the MEK/ERK signalling cascade by AS703026, a novel selective MEK1/2 inhibitor, induces pleiotropic anti-myeloma activity in vitro and in vivo. Br J Haematol 2010, 149(4): 537-549.

73. Yoon J, Koo KH, Choi KY: MEK1/2 inhibitors AS703026 and AZD6244 may be potential therapies for KRAS mutated colorectal cancer that is resistant to EGFR monoclonal antibody therapy. Cancer Res 2011, 71(2):445-453.

74. Macarulla T, Tabernero J, Cervantes A, Roselló S, Van Cutsem E, Tejpar S, Prenen H, Martinelli E, Troiani T, Campana F, Laffranchi B, Jego V, von Richter O, Ciardiello F: Phase I/II study of FOLFIRI plus the MEK1/2 inhibitor pimasertib (MSC1936369b) as second-line treatment for kras mutated metastatic colorectal cancer. Ann Oncol 2012, 23(Suppl 4):PD-0024.

75. Yeh TC, Marsh V, Bernat BA, Ballard J, Colwell H, Evans RJ, Parry J, Smith D, Brandhuber BJ, Gross S, et al: Biological characterization of ARRY-142886 (AZD6244), a potent, highly selective mitogen-activated protein kinase kinase 1/2 inhibitor. Clin Cancer Res 2007, 13(5):1576-1583.

76. Adjei AA, Cohen RB, Franklin W, Morris C, Wilson D, Molina JR, Hanson LJ, Gore L, Chow L, Leong S, et al: Phase I pharmacokinetic and pharmacodynamic study of the oral, small-molecule mitogen-activated protein kinase kinase 1/2 inhibitor AZD6244 (ARRY-142886) in patients with advanced cancers. J Clin Oncol 2008, 26(13):2139-2146.

77. Bennouna J, Lang I, Valladares-Ayerbes M, Boer K, Adenis A, Escudero P, Kim TY, Pover GM, Morris CD, Douillard JY: A Phase II, open-label, randomised study to assess the efficacy and safety of the MEK1/2 inhibitor AZD6244 (ARRY-142886) versus capecitabine monotherapy in patients with colorectal cancer who have failed one or two prior chemotherapeutic regimens. Invest New Drugs 2011, 29(5):1021-1028.

78. Bodoky G, Timcheva C, Spigel DR, La Stella PJ, Ciuleanu TE, Pover G, Tebbutt NC: A phase II open-label randomized study to assess the efficacy and safety of selumetinib (AZD6244 [ARRY-142886]) versus capecitabine in patients with advanced or metastatic pancreatic cancer who have failed first-line gemcitabine therapy. Invest New Drugs 2012, 30(3):1216-1223.

79. Hainsworth JD, Cebotaru CL, Kanarev V, Ciuleanu TE, Damyanov D, Stella P, Ganchev H, Pover G, Morris C, Tzekova V: A phase II, open-label, randomized study to assess the efficacy and safety of AZD6244 (ARRY-142886) versus pemetrexed in patients with non-small cell lung cancer who have failed one or two prior chemotherapeutic regimens. J Thorac Oncol 2010, 5(10):1630-1636.

80. Hayes DN, Lucas AS, Tanvetyanon T, Krzyzanowska MK, Chung CH, Murphy BA, Gilbert J, Mehra R, Moore DT, Sheikh A, et al: Phase II efficacy and pharmacogenomic study of Selumetinib (AZD6244; ARRY-142886) in 
iodine-131 refractory papillary thyroid carcinoma with or without follicular elements. Clin Cancer Res 2012, 18(7):2056-2065.

81. Kirkwood JM, Bastholt L, Robert C, Sosman J, Larkin J, Hersey P, Middleton M, Cantarini M, Zazulina V, Kemsley K, et al: Phase II, open-label, randomized trial of the MEK $1 / 2$ inhibitor selumetinib as monotherapy versus temozolomide in patients with advanced melanoma. Clin Cancer Res 2012, 18(2):555-567.

82. O'Neil BH, Goff LW, Kauh JS, Strosberg JR, Bekaii-Saab TS, Lee RM, Kazi A Moore DT, Learoyd M, Lush RM, et al: Phase II study of the mitogenactivated protein kinase $1 / 2$ inhibitor selumetinib in patients with advanced hepatocellular carcinoma. J Clin Oncol 2011, 29(17):2350-2356.

83. Janne PA, Shaw AT, Pereira JR, Jeannin G, Vansteenkiste J, Barrios C, Franke FA, Grinsted L, Zazulina V, Smith P, et al: Selumetinib plus docetaxel for KRASmutant advanced non-small-cell lung cancer: a randomised, multicentre, placebo-controlled, phase 2 study. Lancet Oncol 2013, 14(1):38-47.

84. Farley J, Brady WE, Vathipadiekal V, Lankes HA, Coleman R, Morgan MA, Mannel R, Yamada SD, Mutch D, Rodgers WH, et al: Selumetinib in women with recurrent low-grade serous carcinoma of the ovary or peritoneum: an open-label, single-arm, phase 2 study. Lancet Oncol 2013, 14(2):134-140.

85. Ho AL, Grewal RK, Leboeuf R, Sherman EJ, Pfister DG, Deandreis D, Pentlow KS, Zanzonico PB, Haque S, Gavane S, et al: Selumetinib-enhanced radioiodine uptake in advanced thyroid cancer. N Engl J Med 2013, 368(7):623-632.

86. Barrett SD, Bridges AJ, Dudley DT, Saltiel AR, Fergus JH, Flamme CM, Delaney AM, Kaufman M, LePage S, Leopold WR, et al: The discovery of the benzhydroxamate MEK inhibitors $\mathrm{Cl}-1040$ and PD 0325901. Bioorg Med Chem Lett 2008, 18(24):6501-6504.

87. Sebolt-Leopold JS, Merriman R, Omer C, Tecle H, Bridges A, Klohs W, Loi C$M$, Valik H, Przybranowski S, Meyer M, et al: The biological profile of PD 0325901: A second generation analog of $\mathrm{Cl}-1040$ with improved pharmaceutical potential. AACR Meeting Abstracts 2004, 2004(1):925.

88. Henderson YC, Chen Y, Frederick MJ, Lai SY, Clayman GL: MEK inhibitor PD0325901 significantly reduces the growth of papillary thyroid carcinoma cells in vitro and in vivo. Mol Cancer Ther 2010, 9(7):1968-1976.

89. Lorusso PM, Adjei AA, Varterasian M, Gadgeel S, Reid J, Mitchell DY, Hanson L, DeLuca P, Bruzek L, Piens J, et al: Phase I and pharmacodynamic study of the oral MEK inhibitor $\mathrm{Cl}-1040$ in patients with advanced malignancies. J Clin Oncol 2005, 23(23):5281-5293.

90. Sheth PR, Liu Y, Hesson T, Zhao J, Vilenchik L, Liu YH, Mayhood TW, Le HV: Fully activated MEK1 exhibits compromised affinity for binding of allosteric inhibitors U0126 and PD0325901. Biochemistry 2011, 50(37):7964-7976.

91. Haura EB, Ricart AD, Larson TG, Stella PJ, Bazhenova L, Miller VA, Cohen RB, Eisenberg PD, Selaru P, Wilner KD, et al: A phase II study of PD-0325901, an oral MEK inhibitor, in previously treated patients with advanced nonsmall cell lung cancer. Clin Cancer Res 2010, 16(8):2450-2457.

92. Iverson C, Larson G, Lai C, Yeh LT, Dadson C, Weingarten P, Appleby T, Vo T, Maderna A, Vernier JM, et al: RDEA119/BAY 869766: a potent, selective, allosteric inhibitor of MEK1/2 for the treatment of cancer. Cancer Res 2009, 69(17):6839-6847.

93. Chang Q, Chapman MS, Miner JN, Hedley DW: Antitumour activity of a potent MEK inhibitor RDEA119/BAY 869766 combined with rapamycin in human orthotopic primary pancreatic cancer xenografts. BMC Cancer 2010, 10:515.

94. Gore L, Lewis K, Von Hoff DD, Weiss GJ, Ramanathan RK, Adjei AA, Dy GK, Ma WW, Clendeninn NJ, Leffingwell DP, et al: Safety, pharmacokinetics, and pharmacodynamics results from a phase I trial of BAY 86-9766 (RDEA119), a MEK inhibitor, in patients with advanced cancer. ASCO Meeting Abstracts 2011, 29(15_suppl):3007.

95. Lim HY, Yen C-J, Tak W-Y, Heo J, Choi HJ, Lin C-Y, Yoon J-H, Hsu C, Rau K-M, Poon RTP, et al: A phase II trial of MEK inhibitor BAY 86-9766 in combination with sorafenib as first-line systemic treatment for patients with unresectable hepatocellular carcinoma (HCC). ASCO Meeting Abstracts 2012, 30(15_suppl):4103.

96. Dong Q, Dougan DR, Gong X, Halkowycz P, Jin B, Kanouni T, O'Connell SM, Scorah N, Shi L, Wallace MB, et al: Discovery of TAK-733, a potent and selective MEK allosteric site inhibitor for the treatment of cancer. Bioorg Med Chem Lett 2011, 21(5):1315-1319.

97. von Euw E, Atefi M, Attar N, Chu C, Zachariah S, Burgess BL, Mok S, Ng C, Wong DJ, Chmielowski B, et al: Antitumor effects of the investigational selective MEK inhibitor TAK733 against cutaneous and uveal melanoma cell lines. Mol Cancer 2012, 11:22.
98. Finn RS, Javle MM, Tan BR, Weekes CD, Bendell JC, Patnaik A, Khan GN, Laheru D, Anderson L, Christy-Bittel JL, et al: A phase I study of MEK inhibitor MEK162 (ARRY-438162) in patients with biliary tract cancer. ASCO Meeting Abstracts 2012, 30(4_suppl):220.

99. Bendell JC, Papadopoulos K, Jones SF, Barrett E, Guthrie K, Kass CL, Litwiler KS, Napier C, Patnaik A: Abstract B243: A phase I dose-escalation study of MEK inhibitor MEK162 (ARRY-438162) in patients with advanced solid tumors. Mol Cancer Ther 2011, 10(Supplement 1):B243.

100. Ascierto PA, Schadendorf D, Berking C, Agarwala SS, van Herpen CM, Queirolo P, Blank CU, Hauschild A, Beck JT, St-Pierre A, et al: MEK162 for patients with advanced melanoma harbouring NRAS or Val600 BRAF mutations: a non-randomised, open-label phase 2 study. Lancet Oncol 2013, 14(3):249-256.

101. Martinez-Garcia M, Banerji U, Albanell J, Bahleda R, Dolly S, Kraeber-Bodere F, Rojo F, Routier E, Guarin E, Xu ZX, et al: First-in-human, phase I doseescalation study of the safety, pharmacokinetics, and pharmacodynamics of RO5126766, a first-in-class dual MEK/RAF inhibitor in patients with solid tumors. Clin Cancer Res 2012, 18(17):4806-4819.

102. Mala C, Neville NG, Haindl E, Buergle M, Schmalix W, Bevan P: A phase I, first-in-human single ascending dose study of the MEK inhibitor WX-554 given to healthy male subjects. ASCO Meeting Abstracts 2010, 28 (15_suppl):e13666.

103. Isshiki Y, Kohchi Y, likura H, Matsubara Y, Asoh K, Murata T, Kohchi M, Mizuguchi E, Tsujii S, Hattori K, et al: Design and synthesis of novel allosteric MEK inhibitor $\mathrm{CH} 4987655$ as an orally available anticancer agent. Bioorg Med Chem Lett 2011, 21(6):1795-1801.

104. Leijen S, Middleton MR, Tresca P, Kraeber-Bodere F, Dieras V, Scheulen ME, Gupta A, Lopez-Valverde V, Xu ZX, Rueger R, et al: Phase I dose-escalation study of the safety, pharmacokinetics, and pharmacodynamics of the MEK inhibitor RO4987655 (CH4987655) in patients with advanced solid tumors. Clin Cancer Res 2012, 18(17):4794-4805.

105. Wong H, Vernillet L, Peterson A, Ware JA, Lee L, Martini JF, Yu P, Li C, Del Rosario G, Choo EF, et al: Bridging the gap between preclinical and clinical studies using pharmacokinetic-pharmacodynamic modeling: an analysis of GDC-0973, a MEK inhibitor. Clin Cancer Res 2012, 18(11):3090-3099.

106. Choo EF, Belvin M, Boggs J, Deng Y, Hoeflich KP, Ly J, Merchant M, Orr C, Plise E, Robarge K, et al: Preclinical disposition of GDC-0973 and prospective and retrospective analysis of human dose and efficacy predictions. Drug Metab Dispos 2012, 40(5):919-927.

107. Hoeflich KP, Merchant M, Orr C, Chan J, Den Otter D, Berry L, Kasman I, Koeppen H, Rice K, Yang NY, et al: Intermittent administration of MEK inhibitor GDC-0973 plus PI3K inhibitor GDC-0941 triggers robust apoptosis and tumor growth inhibition. Cancer Res 2012, 72(1):210-219.

108. LoRusso P, Shapiro G, Pandya SS, Kwak EL, Jones C, Belvin M, Musib LC, de Crespigny A, McKenzie M, Gates MR, et al: A first-in-human phase lb study to evaluate the MEK inhibitor GDC-0973, combined with the pan-PI3K inhibitor GDC-0941, in patients with advanced solid tumors. ASCO Meeting Abstracts 2012, 30(15_suppl):2566.

109. Wallace EM, Lyssikatos J, Blake JF, Marlow A, Greschuk J, Yeh TC, Callejo M, Marsh V, Poch G, Otten J, Hingorani G, Winski SL, Anderson DA, Lee P. Winkler J, Koch K, Davies BR, Jones DC, Logie A, Curtis NJ, Chresta CM, Smith PD, Robinson DT: AZD8330 (ARRY-424704): Preclinical evaluation of a potent, selective MEK $1 / 2$ inhibitor currently in phase I trials. Cancer Res 2009. AACR Annual Meeting Proceedings 2009.

110. Cohen RB, Aamdal S, Nyakas M, Cavallin M, Green D, Learoyd M, Smith I, Kurzrock R: A phase I dose-finding, safety and tolerability study of AZD8330 in patients with advanced malignancies. Eur J Cancer 2013, 49:1521-1529.

111. Ponti G, Tomasi A, Pellacani G: Overwhelming response to Dabrafenib in a patient with double BRAF mutation (V600E; V600M) metastatic malignant melanoma. J Hematol Oncol 2012, 5(1):60.

112. WeiSZ L, Efferth T: Polo-like kinase 1 as target for cancer therapy. Exp Hematol Oncol 2012, 1(1):38.

113. Lamba G, Gupta R, Lee B, Ambrale S, Liu D: Current management and prognostic features for gastrointestinal stromal tumor (GIST). Exp Hematol Oncol 2012, 1(1):14.

114. Faulkner N, LoRusso PM, Guthrie T, Soria J-C, Bahleda R, Bendell JC, Infante JR, Massard C, Van Leeuwen B, Martini J-F, et al: Abstract C197: A phase 1 safety and pharmacokinetic (PK) study of the PI3K inhibitor XL147 
(SAR245408) in combination with erlotinib in patients with advanced solid tumors. Mol Cancer Ther 2009, 8(Supplement 1):C197.

115. Infante JR, Patnaik A, Jones SF, Papadopoulos KP, Bendell JC, Rasco DW, Bellew KM, Cox DS, Durante MG, Park JJ, et al: Abstract B128: A phase IB study of the MEK inhibitor GSK1120212 combined with everolimus in patients with solid tumors: Interim results. Mol Cancer Ther 2011,

10(Supplement 1):B128.

doi:10.1186/1756-8722-6-27

Cite this article as: Akinleye et al:: MEK and the inhibitors: from bench to bedside. Journal of Hematology \& Oncology 2013 6:27.

\section{Submit your next manuscript to BioMed Central and take full advantage of:}

- Convenient online submission

- Thorough peer review

- No space constraints or color figure charges

- Immediate publication on acceptance

- Inclusion in PubMed, CAS, Scopus and Google Scholar

- Research which is freely available for redistribution 